\title{
Carbon degradation in agricultural soils flooded with seawater after managed coastal realignment
}

\author{
Kamilla S. Sjøgaard ${ }^{1}$, Alexander H. Treusch ${ }^{1}$, and Thomas B. Valdemarsen ${ }^{2}$ \\ ${ }^{1}$ Nordcee, Department of Biology, University of Southern Denmark, Odense M, 5230, Denmark \\ ${ }^{2}$ Department of Biology, University of Southern Denmark, Odense M, 5230, Denmark \\ Correspondence to: Kamilla S. Sjøgaard (kamillasjogaard@biology.sdu.dk)
}

Received: 30 September 2016 - Discussion started: 4 November 2016

Revised: 6 July 2017 - Accepted: 28 August 2017 - Published: 29 September 2017

\begin{abstract}
Permanent flooding of low-lying coastal areas is a growing threat due to climate change and related sea-level rise. An increasingly common solution to protect coastal areas lying below sea level is intentional flooding by "managed coastal realignment". However, the biogeochemical implications of flooding agricultural soils with seawater are still not well understood. We conducted a 1-year mesocosm experiment to investigate microbial carbon degradation processes in soils flooded with seawater. Agricultural soils were sampled on the northern coast of the island Fyn (Denmark) at Gyldensteen Strand, an area that was subsequently flooded in a coastal realignment project. We found rapid carbon degradation to $\mathrm{TCO}_{2} 1$ day after experimental flooding and onwards and microbial sulfate reduction established quickly as an important mineralization pathway. Nevertheless, no free sulfide was observed as it precipitated as $\mathrm{Fe}-\mathrm{S}$ compounds with Fe acting as a natural buffer, preventing toxic effects of free sulfide in soils flooded with seawater. Organic carbon degradation decreased significantly after 6 months, indicating that most of the soil organic carbon was refractory towards microbial degradation under the anoxic conditions created in the soil after flooding. During the experiment only 6$7 \%$ of the initial soil organic carbon pools were degraded. On this basis we suggest that most of the organic carbon present in coastal soils exposed to flooding through sea-level rise or managed coastal realignment will be permanently preserved.
\end{abstract}

\section{Introduction}

Sea-level rise driven by global climate change is expected to continue for centuries and will in the near future impact about $70 \%$ of the global coastlines (Church et al., 2013). Rising sea level causes higher and more frequent storm surges and leads to more incidences of floodwaters overtopping and breaking coastal defenses (FitzGerald et al., 2008). Reclaimed coastal areas with low elevation are especially vulnerable to flooding. A low-cost strategy of coastal protection is "managed coastal realignment", whereby old coastal defenses are deliberately breached, and new ones are constructed further inland (Cooper, 2003; French, 2008; Roman and Burdick, 2012). The flooded areas created by managed coastal realignment act as buffer zones, protecting populated areas or valuable assets against flooding (Gedan et al., 2011). There are an increasing number of projects in which coastal soils are flooded with seawater by managed costal realignment and similar techniques (Herbert et al., 2015; Pethick, 2002; Wolters et al., 2005).

Many studies have been performed on freshwater wetlands experiencing salinization from seawater intrusion and less on dyked and drained agricultural soil systems exposed to flooding (Ardon et al., 2016, 2013; Portnoy, 1999; Portnoy and Giblin, 1997). Existing studies show that flooding with seawater has dramatic consequences for soil biogeochemistry. Depending on soil porosity and moisture content, soil environments can have deep oxygen penetration $(75-100 \mathrm{~cm})$ (Dziejowski et al., 1997; MacDonald et al., 1993; Neira et al., 2015), since oxygen $\left(\mathrm{O}_{2}\right)$ can rapidly be supplied from the overlying atmosphere via diffusion. Therefore, surface soils are predominantly oxic environments, in which soil organic matter is degraded by a wide variety of microorgan- 
isms, fungi and fauna (Boer et al., 2005; Kalbitz et al., 2000). Aerobic degradation is catalysed by hydrolytic enzymes and reactive oxygen radicals that can break bonds in refractory organic compounds, such as lignin and cellulose, and facilitate complete degradation of soil organic carbon (SOC) to $\mathrm{CO}_{2}$ (Canfield, 1994). However, when soils are flooded, $\mathrm{O}_{2}$ penetration is dramatically reduced, since $\mathrm{O}_{2}$ solubility in water is low and $\mathrm{O}_{2}$ diffusion in water is $10^{4}$ times slower than in air (Neira et al., 2015). $\mathrm{O}_{2}$ will therefore be depleted by microbial and abiotic $\mathrm{O}_{2}$ consuming processes in soils flooded with seawater, and become anoxic except for the upper few millimetres. In aquatic anoxic soils and sediments, mutualistic consortia of microorganisms degrade organic macromolecules into smaller moieties by the excretion of exoenzymes and extracellular hydrolysis, which are then fermented into smaller organic molecules, mainly acetate (Valdemarsen and Kristensen, 2010). The fermentation products are taken up by other microorganisms and oxidized to carbon dioxide $\left(\mathrm{CO}_{2}\right)$ by the reduction of alternative electron acceptors (e.g. nitrate, Mn oxides, Fe oxides and sulfate) (Arnosti, 2011; Glud, 2008). Sulfate is abundant in seawater, and microbial sulfate reduction (SR) is therefore expected to become a major mineralization pathway in soils flooded with seawater (Sutton-Grier et al., 2011; Weston et al., 2011).

While some studies have looked at SOC mineralization pathways in different types of soils introduced to saltwater (Ardon et al., 2016; Chambers et al., 2013; Neubauer et al., 2013; Weston et al., 2006, 2011), a lot is still unknown about how the dynamics between initial SOC degradation to DOC and the terminal mineralization are affected by the introduction of saltwater (Herbert et al., 2015). Many soils subject to managed coastal realignment contain considerable amounts of SOC (Franzluebbers, 2010; Wolters et al., 2005). The degradation of SOC after flooding will depend on the rate of establishment of heterotrophic microbial communities and their ability to degrade SOC (Schmidt et al., 2011). Labile organic carbon may be easily degraded by marine microorganisms, while more complex organic carbon, and especially structurally complex organic compounds, such as cellulose and lignin, may be virtually non-degradable in anoxic environments (Kim and Singh, 2000; Kristensen and Holmer, 2001). Flooding of coastal soils by sea level rise and coastal realignment may therefore cause significant preservation of the SOC contained in the soils at the time of flooding.

In this study the fate of SOC after flooding with seawater was investigated in soils collected at Gyldensteen Strand on the northern coast of Fyn, Denmark, an area that was designated to be flooded in a coastal realignment project. We were especially interested in following the temporal establishment of dominating microbial pathways and quantifying the rates and temporal trajectories of SOC degradation in newly flooded soils. We hypothesized that (1) total SOC degradation activity in soils after flooding depends on SOC content and lability, and that (2) a large proportion of SOC will be non-degradable due to the anoxic soil condi- tions forming after the flooding. To test these hypotheses we performed parallel mesocosm experiments with two different types of soils that were experimentally flooded with seawater. SOC degradation and other biogeochemical developments in the mesocosms were traced with high temporal and spatial resolution for the next 12 months. The results showed how flooding with seawater impacts $\mathrm{C}$ degradation and soil biogeochemistry and formed the basis for an initial evaluation of potential feedbacks of flooding on atmospheric $\mathrm{CO}_{2}$ concentrations.

\section{Materials and methods}

\subsection{Study site}

This study was conducted in relation to the nature restoration project at Gyldensteen Strand funded by the Danish Aage V.

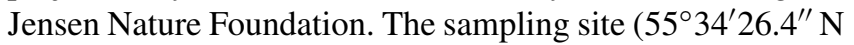
$10^{\circ} 08^{\prime} 17.0^{\prime \prime} \mathrm{E}$ ) was a shallow intertidal habitat until 1871 (size of $\sim 600 \mathrm{ha}$ ), when it was dyked and continuously drained to create new land for agriculture. The reclaimed area was for the following 140 years mainly used for production of different crops such as onions and grains (Stenak, 2005). As a part of the nature restoration project, selected sections of the dykes were removed in March 2014 and 211 ha of the area were permanently flooded with seawater and turned into a shallow and mostly subtidal marine lagoon.

\subsection{Experimental design and sampling}

Sampling for the mesocosm experiment was performed in November 2013, half a year before the flooding of the site, at two different stations representing uncultivated (UC) and cultivated (C) soils (Fig. 1). Station UC was located in an area with low elevation, which never could be properly drained. Station UC was therefore abandoned for agriculture and became a reed swamp that accumulated plant material and litter. Station C, however, resembled the majority of the reflooded area that was farmed since the land reclamation (fertilized, ploughed and used for monoculture; also illustrated in Fig. 1). From each station, 15 soil cores were sampled in $30 \mathrm{~cm}$ long, $8 \mathrm{~cm}$ internal diameter stainless steel core liners. The core liners were hammered $25 \mathrm{~cm}$ down into the soil, dug up with a spade and closed at both ends with rubber stoppers.

In the laboratory, the headspaces of individual soil cores were gently flooded with 22-26 salinity seawater collected from the shoreface directly north of station UC (Fig. 1). Soil cores were then transferred to $70 \mathrm{~L}$ incubation tanks filled with seawater. During the whole experiment the flooded cores were maintained at $15^{\circ} \mathrm{C}$ and kept in darkness. The water in the tanks was rigorously aerated through air diffuser stones and $10-20 \mathrm{~L}$ of the seawater in the tanks was exchanged with fresh seawater (also collected from the shoreface) every 14 days. Thus soil cores were incubated under constant environmental conditions, while factors such as 


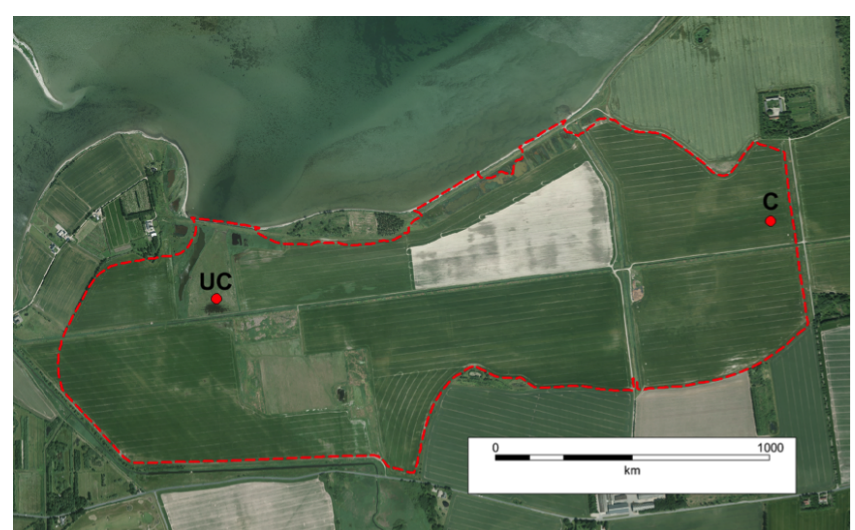

Figure 1. Map of Gyldensteen Strand with the location of the two sampling stations for collecting uncultivated (UC) and cultivated (C) soil cores. The dashed red line indicates the area flooded with seawater in March 2014.

diurnal temperature variations, tidal exchange, benthic primary production and bioturbation were omitted by the experimental set-up.

The flooded soil cores were incubated for 12 months. Flux experiments were conducted with three random soil cores from each station at various times (weekly in the first month, biweekly for the next 3 months and monthly thereafter). Core sectionings were performed on three randomly selected soil cores from each station at different times during the experiment (before the flooding, 1 week after and after 2, 4, 6 and 12 months).

\subsubsection{Flux experiments}

Fluxes of $\mathrm{O}_{2}$, dissolved organic carbon (DOC) and $\mathrm{TCO}_{2}$ $\left(=\mathrm{CO}_{3}^{2-}+\mathrm{HCO}_{3}^{-}+\mathrm{H}_{2} \mathrm{CO}_{3}\right)$ between soil and overlying water were measured regularly, as described above. Cores were equipped with stirring magnets, closed with rubber stoppers and placed around a central magnet rotating at $60 \mathrm{rpm}$ and thereafter incubated for about $4 \mathrm{~h}$ in darkness. $\mathrm{O}_{2}$ was measured and water samples were taken in the headspace of the soil cores at the beginning and end of incubations. $\mathrm{O}_{2}$ was measured with an optical dissolved oxygen meter (YSI ProODO). DOC samples were stored at $-20^{\circ} \mathrm{C}$ until analysis using a Shimadzu TOC-5000 total organic carbon analyser. Samples for $\mathrm{TCO}_{2}$ analysis were kept in $3 \mathrm{~mL}$ gas-tight Exetainers for a maximum of 1 week until analysis by flow injection (Hall and Aller, 1992).

\subsubsection{Core sectioning}

Core sectioning was performed by slicing each soil core into 6 depth intervals $(0-1,1-2,3-5,5-10,10-15$ and $15-20 \mathrm{~cm})$. Porewater was extracted from each depth interval by centrifugation and GF/C filtration in double centrifuge tubes $(500 \mathrm{~g}, 10 \mathrm{~min})$. The porewater was sampled for various pa- rameters: $500 \mu \mathrm{L}$ porewater was preserved with $30 \mu \mathrm{L}$ saturated $\mathrm{HgCl}_{2}$ for $\mathrm{TCO}_{2}, 250 \mu \mathrm{L}$ porewater were preserved with $50 \mu \mathrm{L} 1 \mathrm{M}$ zinc acetate ( $\mathrm{ZnAc}$ ) for total dissolved sulfide $\left(\mathrm{TH}_{2} \mathrm{~S}=\mathrm{H}_{2} \mathrm{~S}+\mathrm{HS}^{-}+\mathrm{S}_{2}^{-}\right)$analysis, $250 \mu \mathrm{L}$ porewater were preserved with $100 \mu \mathrm{L} 0.5 \mathrm{M} \mathrm{HCl}$ for $\mathrm{Fe}^{2+}$ analysis and the remaining porewater was stored at $-20^{\circ} \mathrm{C}$ until analysis for sulfate $\left(\mathrm{SO}_{4}^{2-}\right)$ and DOC. $\mathrm{TCO}_{2}$ and DOC samples were stored and analysed as described above. $\mathrm{TH}_{2} \mathrm{~S}$ samples were analysed using the method of Cline (1969). $\mathrm{Fe}^{2+}$ samples were analysed using the ferrozine method (Stookey, 1970). $\mathrm{SO}_{4}^{2-}$ was analysed using liquid ion chromatography on a Dionex ICS-2000 system.

Reactive iron, $\mathrm{RFe}$, was extracted from soil subsamples from every depth interval with $0.5 \mathrm{M} \mathrm{HCl}$ for $30 \mathrm{~min}$ while being shaken (Lovley and Phillips, 1987). After centrifugation $(500 \mathrm{~g}, 10 \mathrm{~min})$ the supernatant was transferred to sampling vials and stored at room temperature until analysis for reactive $\mathrm{Fe}(\mathrm{II})$ and $\mathrm{Fe}(\mathrm{III})$ - $\mathrm{RFe}(\mathrm{II})$ and $\mathrm{RFe}(\mathrm{III})$, respectively. The supernatant was analysed for $\mathrm{Fe}^{2+}$ and $\mathrm{RFe}$ using the ferrozine method (Stookey, 1970) before and after reduction with hydroxylamine (Lovley and Phillips, 1987). RFe(II) was calculated directly, while RFe(III) was calculated from the difference between RFe and RFe(II). An estimate of total $\mathrm{Fe}$ content was obtained by boiling combusted soil subsamples in $1 \mathrm{M} \mathrm{HCl}$ for $1 \mathrm{~h}$ at $120^{\circ} \mathrm{C}$. The supernatant was stored at room temperature until analysis by the ferrozine method.

Acid volatile sulfides (AVS) (Rickard and Morse, 2005) and chromium reducible sulfides (CRS) were determined on soil subsamples preserved with $1 \mathrm{M} \mathrm{ZnAc}$ and stored at $-20^{\circ} \mathrm{C}$ until analysis. AVS and CRS were extracted by 2-step distillation as described in Fossing and Jørgensen (1998). Sulfide concentrations in the distillates were analysed using the method described by Cline (1969).

Soil characteristics were also determined for every depth interval during every core sectioning. Soil density was determined gravimetrically and soil subsamples were dried $(24 \mathrm{~h}$, $105^{\circ} \mathrm{C}$ ) to determine water content and porosity. Soil organic matter content was measured as the weight loss of dry sediment after combustion $\left(520^{\circ} \mathrm{C}, 5 \mathrm{~h}\right)$. SOC on selected soil samples (samples obtained after 1 week and 6 months) was also measured by elemental analysis with a Carlo Erba CHN EA-1108 elemental analyzer according to Kristensen and Andersen (1987).

\subsubsection{Anoxic incubations (jar experiments)}

Depth distributions of microbial $\mathrm{TCO}_{2}$ and DOC production and SR were estimated from anoxic soil incubations (Kristensen and Hansen, 1995; Quintana et al., 2013). The excess soil from core sectionings was pooled into four depth intervals $(0-2,2-5,5-10$ and $15-20 \mathrm{~cm})$, thoroughly homogenized and tightly packed into 6-8 glass scintillation vials $(20 \mathrm{~mL})$. The vials were closed with screw caps, buried headdown in anoxic mud and incubated at $15^{\circ} \mathrm{C}$ in darkness. Two jars from each jar series were used every week for pore- 
water extraction in the following 4 weeks. The screw caps were changed to a perforated lid containing a GF/C filter and the jars were centrifuged upside-down in a centrifuge tube $(10 \mathrm{~min}$ at $500 \mathrm{~g})$. The extracted porewater was sampled and analysed for $\mathrm{TCO}_{2}$, DOC and $\mathrm{SO}_{4}^{2-}$ as described above.

\subsection{Data analysis}

Fluxes of $\mathrm{TCO}_{2}$, DOC and $\mathrm{O}_{2}$ were calculated from the concentration differences between start and end samples. Microbial rates in jar experiments $\left(\mathrm{DOC}\right.$ and $\mathrm{TCO}_{2}$ production and $\mathrm{SR}$ ) were calculated for $0-2,2-5,5-10,15-20 \mathrm{~cm}$ depth intervals by fitting the time-dependent concentration changes by linear regressions after removing obvious outliers (visual check). When the slopes were significant $(p<0.05)$, the volume specific reaction rates $\left(\mathrm{nmol} \mathrm{cm}{ }^{-3} \mathrm{~d}^{-1}\right)$ in individual depth layers were calculated from the regression slopes corrected for sediment porosity. Microbial reaction rates, porewater and solid pools were depth integrated over $0-20 \mathrm{~cm}$ and converted to area-specific units. Linear data interpolation was used to correct for missing data points, e.g. for the depth interval $10-15 \mathrm{~cm}$ at which microbial rates were not measured. There was a significant linear correlation between organic matter content and SOC for both sampling stations $\left[\mathrm{OC}(\%)=0.442 \cdot \mathrm{LOI}(\%)+0.178, r^{2}=0.987, n=\right.$ 36]. This correlation was used to convert organic matter into SOC for the time points at which SOC was not directly measured. A one-way ANOVA was performed on area-specific SOC pools at the different time points to test for significant changes in the SOC pools over time. Depth-integrated SR rates were normalized to $\mathrm{C}$ units since an almost $2: 1$ relationship between $\mathrm{TCO}_{2}$ production and SR (Jørgensen, 2006) was observed throughout the experiment. Errors for soil characteristics, fluxes, porewater and solid pools were calculated as standard errors of the mean (SEM). Errors for depth-integrated values of microbial rates and solid pools were calculated as standard errors propagation (SEP) of standard deviation (SD) values following \pm Eq. (1):

$\mathrm{SEP}=\sqrt{\mathrm{SD}_{0-1 \mathrm{~cm}}^{2}+\ldots+\mathrm{SD}_{15--20 \mathrm{~cm}}^{2}}$.

In a carbon budget estimating SOC degradation during the experiment, total degradation of SOC $\left(\mathrm{mol} \mathrm{m}^{2}\right)$ was calculated as the sum of the time integrated $\mathrm{TCO}_{2}$ efflux, timeintegrated DOC efflux and area-specific $\mathrm{TCO}_{2}$ and DOC in porewater by the end of the experiment. The percentage of the initial SOC pool degraded during the experiment was calculated from the estimated total degradation of SOC and mean bulk SOC pool. In a time-specific carbon degradation budget, total degradation to $\mathrm{TCO}_{2}$ was calculated as the sum of time-integrated $\mathrm{TCO}_{2}$ efflux and accumulated porewater $\mathrm{TCO}_{2}$ at different time points after flooding (1 week and 2, 4, 6 and 12 months). Based on the jar experiments, total anaerobic $\mathrm{TCO}_{2}$ production and $\mathrm{TCO}_{2}$ production by SR (according to a $2: 1$ relationship between $\mathrm{TCO} 2$ production and $\mathrm{SR}$ )
Table 1. Mean values of water content, porosity and soil organic carbon (SOC) for all core sectionings. Error indicated as SEM ( $n=$ $15)$.

\begin{tabular}{rrrrr}
\hline & $\begin{array}{r}\text { Depth } \\
(\mathrm{cm})\end{array}$ & $\begin{array}{r}\text { Water } \\
\text { content } \\
(\%)\end{array}$ & Porosity & $\begin{array}{r}\text { SOC } \\
(\%)\end{array}$ \\
\hline & 0.5 & $82.9 \pm 0.7$ & $0.82 \pm 0.04$ & $16.2 \pm 0.8$ \\
& 1.5 & $75.5 \pm 1.6$ & $0.97 \pm 0.02$ & $16.1 \pm 1.2$ \\
Station UC & 3.5 & $60.5 \pm 1.8$ & $0.79 \pm 0.01$ & $11.0 \pm 0.8$ \\
& 7.5 & $39.3 \pm 0.9$ & $0.60 \pm 0.01$ & $5.2 \pm 0.2$ \\
& 12.5 & $33.0 \pm 0.7$ & $0.54 \pm 0.01$ & $3.5 \pm 0.2$ \\
& 17.5 & $34.5 \pm 0.8$ & $0.56 \pm 0.01$ & $3.5 \pm 0.2$ \\
\hline & 0.5 & $32.0 \pm 0.6$ & $0.58 \pm 0.02$ & $1.4 \pm 0.0$ \\
& 1.5 & $24.8 \pm 0.5$ & $0.53 \pm 0.01$ & $1.1 \pm 0.0$ \\
& 3.5 & $21.6 \pm 0.3$ & $0.40 \pm 0.01$ & $1.0 \pm 0.0$ \\
& 7.5 & $18.9 \pm 0.4$ & $0.35 \pm 0.01$ & $0.8 \pm 0.1$ \\
& 12.5 & $17.9 \pm 0.3$ & $0.34 \pm 0.00$ & $0.9 \pm 0.0$ \\
& 17.5 & $19.8 \pm 0.4$ & $0.37 \pm 0.01$ & $1.0 \pm 0.0$ \\
\hline
\end{tabular}

was calculated by time integration at different time points after flooding (1 week and 2, 4, 6 and 12 months). Relative contributions of SR to anaerobic degradation to $\mathrm{TCO}_{2}$ were estimated from $\mathrm{TCO}_{2}$ production and $\mathrm{TCO}_{2}$ production by SR measured in jar experiments.

\section{Results}

\subsection{Soil characteristics}

Soil at the two sampled stations had a very different appearance, as a result of different use after land reclamation (i.e. no cultivation and cultivation). Station UC was overgrown with mosses and grasses, and a dense layer of roots and litter characterized the upper $5 \mathrm{~cm}$ of the soil, while the deeper parts of the soil ( $>10 \mathrm{~cm}$ depth) consisted of clay. At station $\mathrm{C}$ only relatively small amounts of grass and root material were evident in the upper $5 \mathrm{~cm}$. Some of the vegetation was still alive 2 months after the flooding, as indicated by long green grass leaves seeking light, but it slowly died out thereafter. The soil at both stations contained partially degraded shell material from gastropods and bivalves remaining from before 1871, when the area was a marine lagoon.

There was very little variation in the soil characteristics between successive core sectionings, so results were averaged for the whole experiment (Table 1). The water content at station UC decreased with depth from $83 \%$ at the top to $35 \%$ at the bottom, while water content only decreased from 32 to $20 \%$ at station C. The same depth trend was observed for porosity. The high water content and porosity at station UC was caused by high amounts of plant material (e.g. roots), while the soil at station $\mathrm{C}$ was sandy, homogenous and poor in organic debris. 
Soil organic content varied greatly with depth at station UC, and the topsoil was enriched with SOC (16\%) in contrast to the bottom (1\%) (Table 1). SOC varied between 0.8 and $1.4 \%$ at station $\mathrm{C}$ but there was no variation in depth. A one-way ANOVA showed no significant difference between the SOC contents at the different time points at either station $\mathrm{UC}$ or $\mathrm{C}$ (df $=17, F=1.9, p=1.16$ for both stations).

\section{2 $\mathrm{CO}_{2}$ and DOC efflux, and $\mathrm{O}_{2}$ consumption}

$\mathrm{TCO}_{2}$ effluxes in UC soil were highest at the beginning of the experiment with a maximum of $239 \pm 30 \mathrm{mmol} \mathrm{m}^{-2} \mathrm{~d}^{-1}$ measured on day 13 (Fig. 2a). Subsequently it decreased to about $130 \mathrm{mmol} \mathrm{m}^{-2} \mathrm{~d}^{-1} 31-199$ days after flooding and stabilized around $67 \mathrm{mmol} \mathrm{m}^{-2} \mathrm{~d}^{-1}$ from day 220 to the end. The $\mathrm{TCO}_{2}$ effluxes in $\mathrm{C}$ soil were relatively constant around an average of $29 \mathrm{mmol} \mathrm{m}^{-2} \mathrm{~d}^{-1}$.

High DOC efflux was evident 1 day after flooding at station UC $\left(108 \pm 3 \mathrm{mmol} \mathrm{m}^{-2} \mathrm{~d}^{-1}\right)$ (Fig. 2b), but it decreased to around $60 \mathrm{mmol} \mathrm{m}^{-2} \mathrm{~d}^{-1} 6-20$ days after flooding and to $17 \mathrm{mmol} \mathrm{m}^{-2} \mathrm{~d}^{-1}$ after approximately 2 months before the end. DOC effluxes at station $\mathrm{C}$ showed a similar pattern, averaging $25 \mathrm{mmol} \mathrm{m}^{-2} \mathrm{~d}^{-1}$ in the first 2 months after flooding and decreasing to an average of $5 \mathrm{mmol} \mathrm{m}^{-2} \mathrm{~d}^{-1}$ for the remaining time of the experiment.

$\mathrm{O}_{2}$ consumption decreased almost linearly during the 1-year experiment on both stations (Fig. 2c). At station UC initial $\mathrm{O}_{2}$ consumption was $57 \pm 3 \mathrm{mmolm}^{-2} \mathrm{~d}^{-1}, 1-$ 45 days after flooding, and then it steadily decreased to $19 \pm 3 \mathrm{mmol} \mathrm{m}^{-2} \mathrm{~d}^{-1}$ by the end. At station $\mathrm{C}$ there was a less pronounced temporally decreasing trend. $\mathrm{O}_{2}$ consumption was highest initially with about $26 \mathrm{mmol} \mathrm{m}^{-2} \mathrm{~d}^{-1}$ at day $1-13$ and then decreased to $9 \pm 0.6 \mathrm{mmol} \mathrm{m}^{-2} \mathrm{~d}^{-1}$ by the end.

\subsubsection{Porewater chemistry}

Porewater DOC was high 1 week after flooding at both stations (on average 10.4 and $3.8 \mathrm{mM}$ at stations $\mathrm{UC}$ and C, respectively; Fig. 3a). Over the experiment porewater DOC decreased slightly in UC soil, while it increased slightly in $\mathrm{C}$ soil.

Porewater $\mathrm{TCO}_{2}$ concentrations in UC soil were in the range of 5-13 mM between 1 week and 2 months after flooding, and profiles showed a slightly increasing pattern with depth (Fig. 3b). Afterwards an unexpected drop in $\mathrm{TCO}_{2}$ concentrations, especially in the deep soil ( $>2 \mathrm{~cm}$ depth), was observed. This was likely an experimental artefact; however, it was caused by extremely high $\mathrm{Fe}^{2+}$ concentrations $>2 \mathrm{mM}$ in the porewater. During sample storage the $\mathrm{Fe}^{2+}$ was oxidized to Fe-oxyhydroxides and formed an orangebrown precipitate at the bottom of the sample containers, probably leading to sample acidification and $\mathrm{TCO}_{2}$ degassing (Moses et al., 1987; Hedin, 2006). Porewater $\mathrm{TCO}_{2}$ concentrations in UC soil after 4 months were affected by this artefact. In $\mathrm{C}$ soil, porewater $\mathrm{Fe}^{2+}$ did not accumulate at the
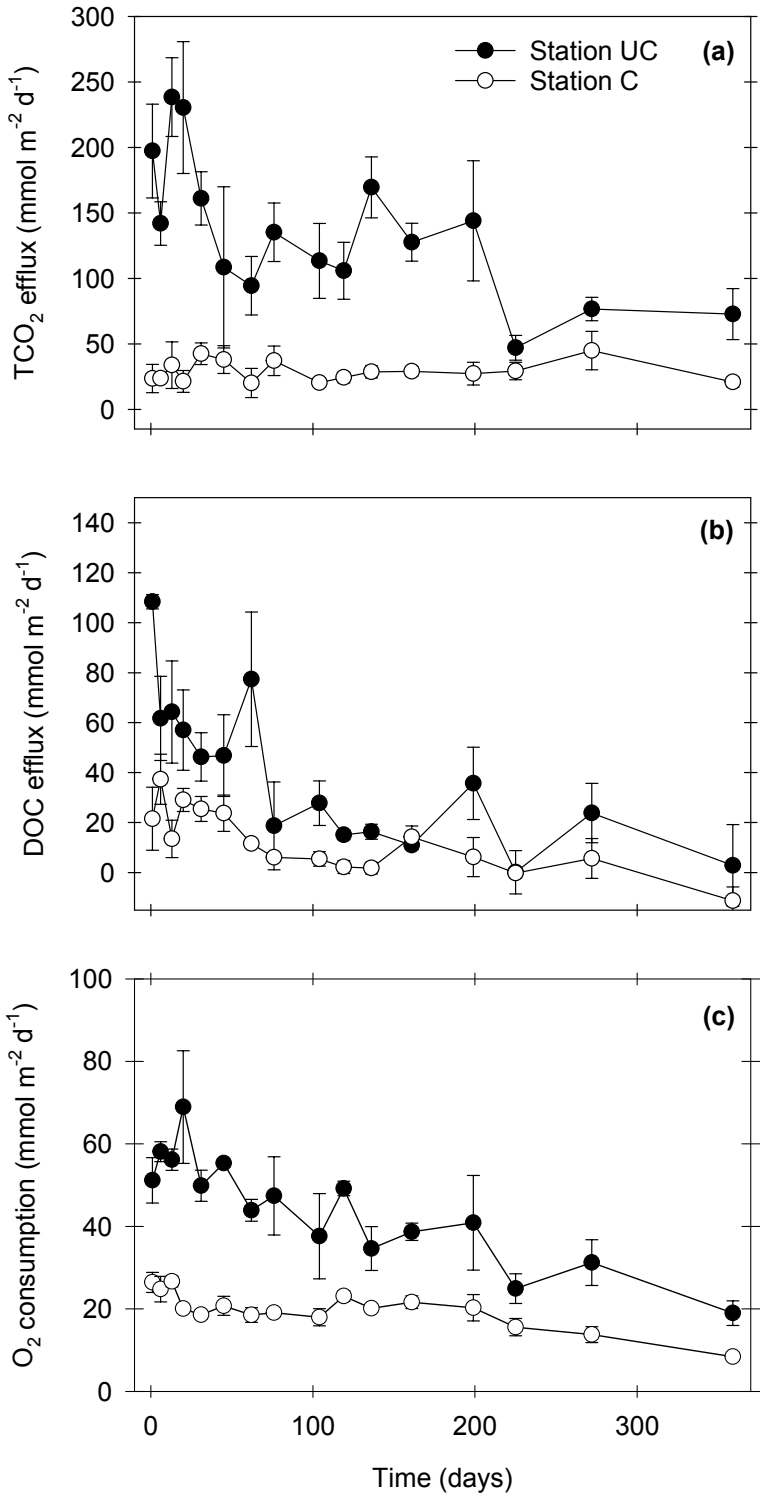

Figure 2. Fluxes of total carbon dioxide $\left(\mathrm{TCO}_{2}\right.$, a), dissolved organic carbon (DOC, b) and oxygen $\left(\mathrm{O}_{2}\right)$ consumption (c) in soil cores with uncultivated (UC) and cultivated (C) soil after flooding. Error bars indicate SEM $(n=3)$.

same rate as in UC soil and only exceeded $2 \mathrm{mM}$ in the 10 $20 \mathrm{~cm}$ depth layer after 6 months. Here porewater $\mathrm{TCO}_{2}$ accumulated gradually over time as expected (Fig. 3b). Rapid $\mathrm{TCO}_{2}$ accumulation occurred in the first 2 months, when $\mathrm{TCO}_{2}$ increased from $3-5$ to $11 \mathrm{mM}$ below $3 \mathrm{~cm}$ depth. After 2 months, $\mathrm{TCO}_{2}$ increased further in the $2-10 \mathrm{~cm}$ depth interval, while a decrease occurred below $10 \mathrm{~cm}$ depth, which was probably related to $\mathrm{Fe}^{2+}$ exceeding $2 \mathrm{mM}$.

High concentrations of $\mathrm{SO}_{4}^{2-}$ were introduced to the soil when it was flooded with seawater. Yet the initial water infiltration and diffusion was the only transport mechanism for dissolved $\mathrm{SO}_{4}^{2-}$ in the mesocosm set-up, and the experimen- 

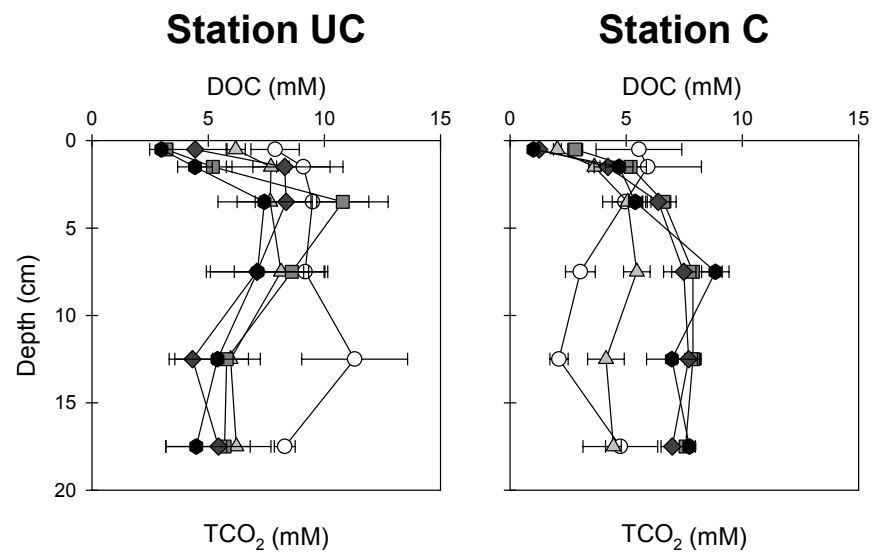

(a)
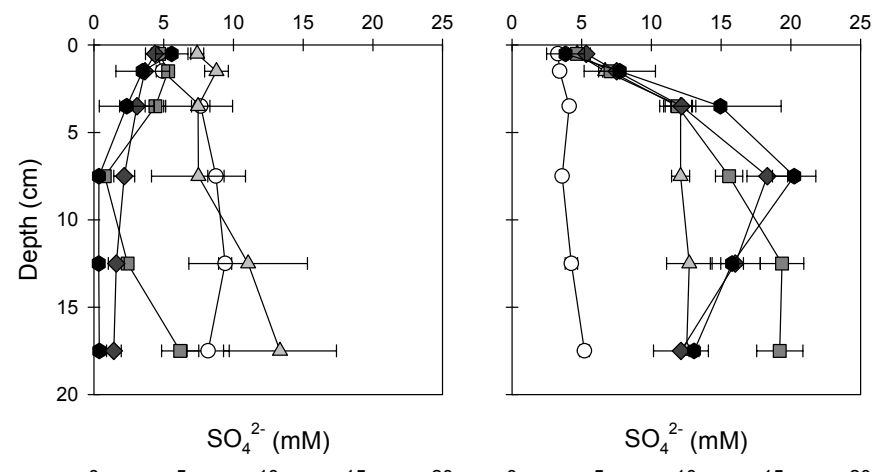

(b)
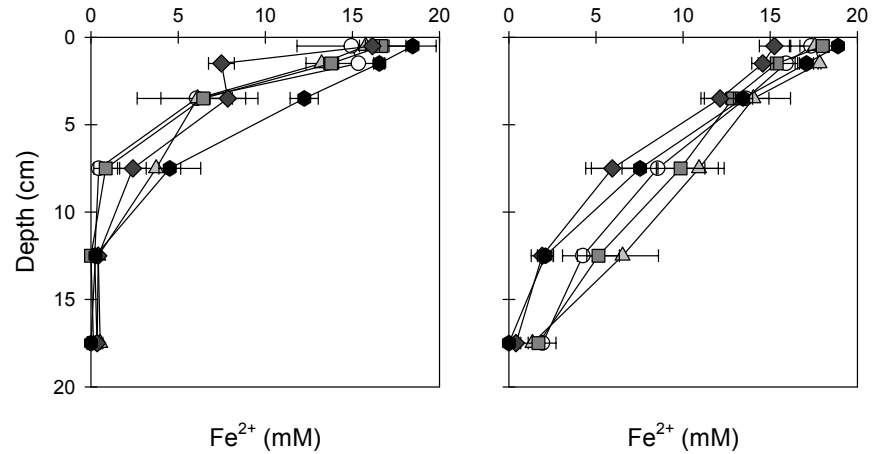

(c)
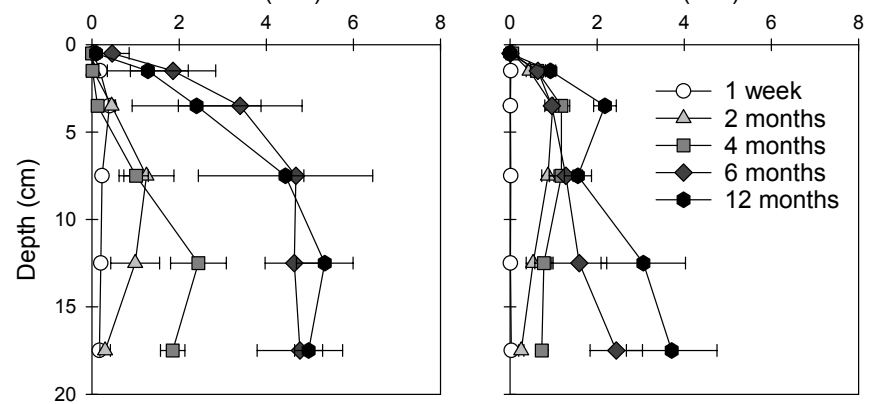

(d)

Figure 3. Porewater profiles for dissolved organic carbon (DOC, a), total carbon dioxide $\left(\mathrm{TCO}_{2}, \mathbf{b}\right)$, sulfate $\left(\mathrm{SO}_{4}^{2-}\right)(\mathbf{c})$ and $\mathrm{Fe}{ }^{2+}(\mathbf{d})$ in uncultivated (UC) and cultivated (C) soil flooded with seawater. Error bars indicate SEM $(n=3)$.

tal period was evidently not sufficiently long to achieve equilibrium in $\mathrm{SO}_{4}^{2-}$ in porewater concentrations down to $20 \mathrm{~cm}$ depth. As a result, porewater $\mathrm{SO}_{4}^{2-}$ decreased steeply with depth at both stations (Fig. 3c). By the end of the experiment in $\mathrm{UC}$ soil, $\mathrm{SO}_{4}^{2-}$ decreased from $\sim 17 \mathrm{mM}$ at the surface to zero below $10 \mathrm{~cm}$ depth. In $\mathrm{C}$ soil $\mathrm{SO}_{4}^{2-}$ decreased linearly from $\sim 17 \mathrm{mM}$ at the surface to $0-2 \mathrm{mM}$ at the bottom.

After 7 days of flooding the $\mathrm{Fe}^{2+}$ depth distribution in porewater was constant with depth, with on average 0.02 and $0.2 \mathrm{mM}$ at stations $\mathrm{UC}$ and C, respectively (Fig. 3d). Af- 
Station UC
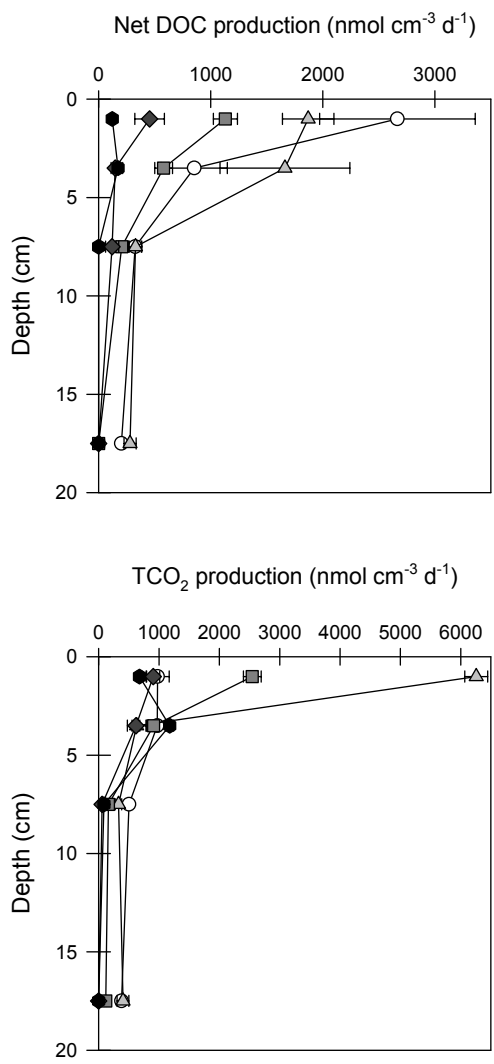

$\mathrm{SR}\left(\mathrm{nmol} \mathrm{cm} \mathrm{c}^{-3} \mathrm{~d}^{-1}\right)$

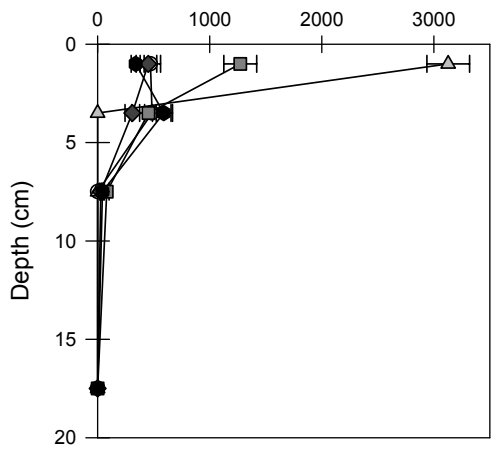

Station C

Net DOC production ( $\mathrm{nmol} \mathrm{cm} \mathrm{cm}^{-1}$ )

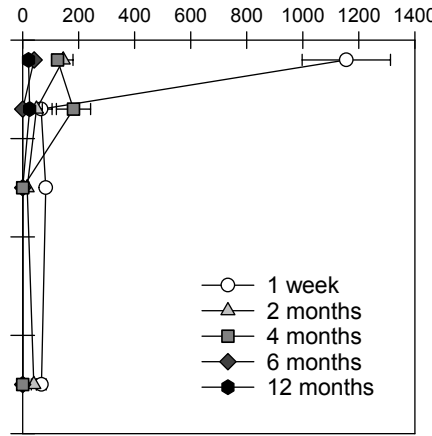

(a)
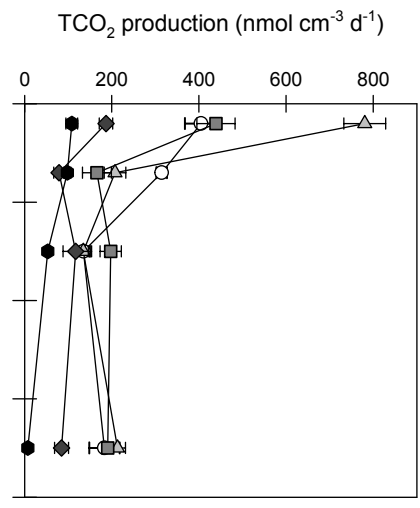

(b)

(c)

Figure 4. Temporal and spatial variability in production of dissolved organic carbon (DOC, a) and carbon dioxide (TCO 2 , b) and sulfate reduction (SR, c) measured in jar experiments with uncultivated (UC) and cultivated (C) soils flooded with seawater. Note the different $x$ axis scaling for UC and C measurements. Error bars indicate SEM.

terwards a progressive increase in porewater $\mathrm{Fe}^{2+}$ was observed at both stations. At station $\mathrm{UC} \mathrm{Fe}^{2+}$ increased to up to $1.3 \pm 0.6 \mathrm{mM}$ at $5-15 \mathrm{~cm}$ depth after 2 months and stabilized after 6 months, when $\mathrm{Fe}^{2+}$ exceeded $4 \mathrm{mM}$ below $5 \mathrm{~cm}$ depth. The same trend was observed at station $\mathrm{C}$, where $\mathrm{Fe}^{2+}$ accumulated to up to $3.7 \mathrm{mM}$ at $15-20 \mathrm{~cm}$ depth after 12 months.

\subsection{Anaerobic net DOC production in jar experiments}

Net DOC production after 1 week of flooding was high at the surface $0-2 \mathrm{~cm}$ at station UC $\left(2666 \pm 695 \mathrm{nmol} \mathrm{cm}^{-3} \mathrm{~d}^{-1}\right.$; Fig. 4a) and decreased exponentially with depth to $203 \pm$ $23 \mathrm{nmol} \mathrm{cm}{ }^{-3} \mathrm{~d}^{-1}$ at $15-20 \mathrm{~cm}$ depth. A gradually decreasing net DOC production was observed in all depth layers over the experiment, and by the end significant net DOC pro- 

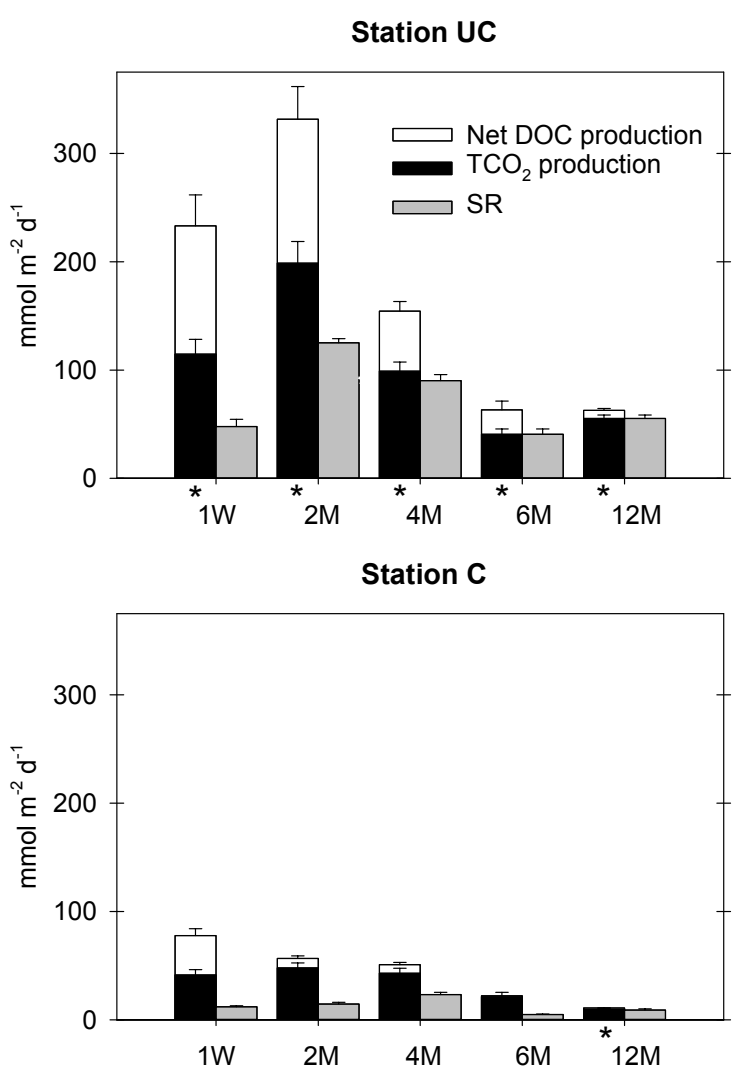

Figure 5. Results from jar experiments showing area-specific net production of dissolved organic carbon (DOC) and total carbon dioxide $\left(\mathrm{TCO}_{2}\right)$, and sulfate reduction ( $\mathrm{SR}$, based on SR rate measurements converted to $\mathrm{C}$ units) in uncultivated (UC) and cultivated (C) soil at different times after flooding at 1 week (1W) and 2, 4, 6 and 12 months (2M, 4M, 6M and 12M), respectively. In columns marked with $*, \mathrm{TCO}_{2}$ production was corrected with $2 \cdot \mathrm{SR}$. Error bars indicate $\operatorname{SEP}(n=4)$.

duction (121-172 $\mathrm{nmol} \mathrm{cm}^{-3} \mathrm{~d}^{-1}$ ) was only detected in the upper $0-5 \mathrm{~cm}$. A similar pattern in net DOC production was observed at station $\mathrm{C}$, although rates were much lower than at station UC. After 1 week of flooding, net DOC production at station $\mathrm{C}$ was $1155 \pm 158 \mathrm{nmol} \mathrm{cm}^{-3} \mathrm{~d}^{-1}$ in the upper 0 $2 \mathrm{~cm}$ of the soil but only $66-83 \mathrm{nmol} \mathrm{cm}^{-3} \mathrm{~d}^{-1}$ below. After 4 months it had decreased to $135 \mathrm{nmol} \mathrm{cm}^{-3} \mathrm{~d}^{-1}$ in the top $0-2 \mathrm{~cm}$ and no net DOC production was detected below $5 \mathrm{~cm}$ depth. Very low rates $\left(21-25 \mathrm{nmol} \mathrm{cm}^{-3} \mathrm{~d}^{-1}\right)$ were detected in the top $0-5 \mathrm{~cm}$ by the end.

Depth-integrated net DOC production at station UC was initially $118-133 \mathrm{mmol} \mathrm{m}^{-2} \mathrm{~d}^{-1}$ in the first 2 months after flooding and then gradually declined to $8 \mathrm{mmol} \mathrm{m}^{-2} \mathrm{~d}^{-1}$ after 12 months (Fig. 5). Initial depth-integrated net DOC production at station $\mathrm{C}$ was 4 -fold lower than at station UC. Net DOC production in $\mathrm{C}$ soil decreased by $75 \%$ in the first 2 months after flooding and almost no net DOC production occurred after 6 months.

\subsection{Anaerobic $\mathrm{TCO}_{2}$ production in jar experiments}

Initial depth trends in $\mathrm{TCO}_{2}$ production were generally similar to those observed for DOC, but temporal trends were markedly different (Fig. 4b). At station $\mathrm{UC}, \mathrm{TCO}_{2}$ production was initially almost $1000 \mathrm{nmol} \mathrm{cm}^{-3} \mathrm{~d}^{-1}$ in the top $0-2 \mathrm{~cm}$ and decreased to $380 \mathrm{nmol} \mathrm{cm}^{-3} \mathrm{~d}^{-1}$ at $15-20 \mathrm{~cm}$ depth. After 2 months, $\mathrm{TCO}_{2}$ production had increased in the surface $0-2 \mathrm{~cm}$ to $6250 \mathrm{nmol} \mathrm{cm}^{-3} \mathrm{~d}^{-1}$, while rates below $10 \mathrm{~cm}$ depth remained relatively low. After 4 months, $\mathrm{TCO}_{2}$ production decreased to about $2500 \mathrm{nmol} \mathrm{cm}^{-3} \mathrm{~d}^{-1}$ in the top $0-2 \mathrm{~cm}$, while it was not possible to determine $\mathrm{TCO}_{2}$ production rates directly for soil deeper than $5 \mathrm{~cm}$ due to the problem with extremely high porewater $\mathrm{Fe}^{2+}$ described above. As seen below, porewater $\mathrm{SO}_{4}^{2-}$ concentrations were not affected by the high porewater $\mathrm{Fe}^{2+}$ concentrations. For the affected data points $\mathrm{TCO}_{2}$ production was calculated as a rate of $\mathrm{SR} \times 2$, assuming that $\mathrm{SR}$ was the dominating $\mathrm{CO}_{2}$ producing process in the anoxic soil (Jørgensen, 2006). The calculations showed that $\mathrm{TCO}_{2}$ production had decreased further after 6 and 12 months in the top $5 \mathrm{~cm}\left(600-1000 \mathrm{nmol} \mathrm{cm}^{-3} \mathrm{~d}^{-1}\right)$ and was quite stable below $\left(0-85 \mathrm{nmol} \mathrm{cm}^{-3} \mathrm{~d}^{-1}\right) . \mathrm{TCO}_{2}$ production rates were generally much lower in $\mathrm{C}$ soil, while relative trends for $\mathrm{TCO}_{2}$ production and their development over time were quite similar between stations. Maximum $\mathrm{TCO}_{2}$ production rates occurred at $0-2 \mathrm{~cm}$ depth, where $\mathrm{TCO}_{2}$ production varied from 400 to $780 \mathrm{nmol} \mathrm{cm}^{-3} \mathrm{~d}^{-1}$ between 1 week and 2 months and then gradually decreased to $110 \mathrm{nmol} \mathrm{cm}^{-3} \mathrm{~d}^{-1}$ by the end. Similar trends were observed in the deeper soil, where $\mathrm{TCO}_{2}$ production decreased from 180 to $310 \mathrm{nmol} \mathrm{cm}^{-3} \mathrm{~d}^{-1}$ after 7 days to $7-53 \mathrm{nmol} \mathrm{cm}^{-3} \mathrm{~d}^{-1}$ after 12 months.

Area-specific $\mathrm{TCO}_{2}$ production at station $\mathrm{UC}$ was initially $115-200 \mathrm{mmol} \mathrm{m}^{-2} \mathrm{~d}^{-1}$ in the first 2 months, and decreased to $40 \mathrm{mmol} \mathrm{m}^{-2} \mathrm{~d}^{-1}$ after 6 months (Fig. 5). At station $\mathrm{C}$ area specific $\mathrm{TCO}_{2}$ production was relatively stable around $44 \mathrm{mmol} \mathrm{m}^{-2} \mathrm{~d}^{-1}$ for the first 4 months and decreased to 21 and $10 \mathrm{mmol} \mathrm{m}^{-2} \mathrm{~d}^{-1}$ after 6 and 12 months, respectively.

\section{5 $\mathrm{SR}$ in jar experiments}

Significant SR was measured in the top $0-5 \mathrm{~cm}$ $\left(470 \mathrm{mmol} \mathrm{m}^{-2} \mathrm{~d}^{-1}\right)$ in UC soil 1 week after flooding, while no SR was detected below (Fig. 4c). After 2 months, high SR was only measured in the top $0-2 \mathrm{~cm}$ $\left(3128 \pm 190 \mathrm{mmol} \mathrm{m}^{-2} \mathrm{~d}^{-1}\right)$. After 4 months SR was still highest in the topsoil $\left(1217 \pm 147 \mathrm{mmolm}^{-2} \mathrm{~d}^{-1}\right)$, while significant SR was detected down to $10 \mathrm{~cm}$ depth. From 4 months to the end of the experiment, SR gradually decreased at all depths to $338 \pm 147$ and $43 \pm 6 \mathrm{mmolm}^{-2} \mathrm{~d}^{-1}$ at $0-2$ and $5-10 \mathrm{~cm}$ depth, respectively. Since $\mathrm{SO}_{4}^{2-}$ did not reach the bottom $(15-20 \mathrm{~cm})$ during the experiment at station UC, no SR occurred here. In C soil SR occurred at considerably lower rates than in UC soil. After 1 week SR was $177 \pm 25 \mathrm{mmol} \mathrm{m}^{-2} \mathrm{~d}^{-1}$ at $0-2 \mathrm{~cm}$ depth and decreased ex- 

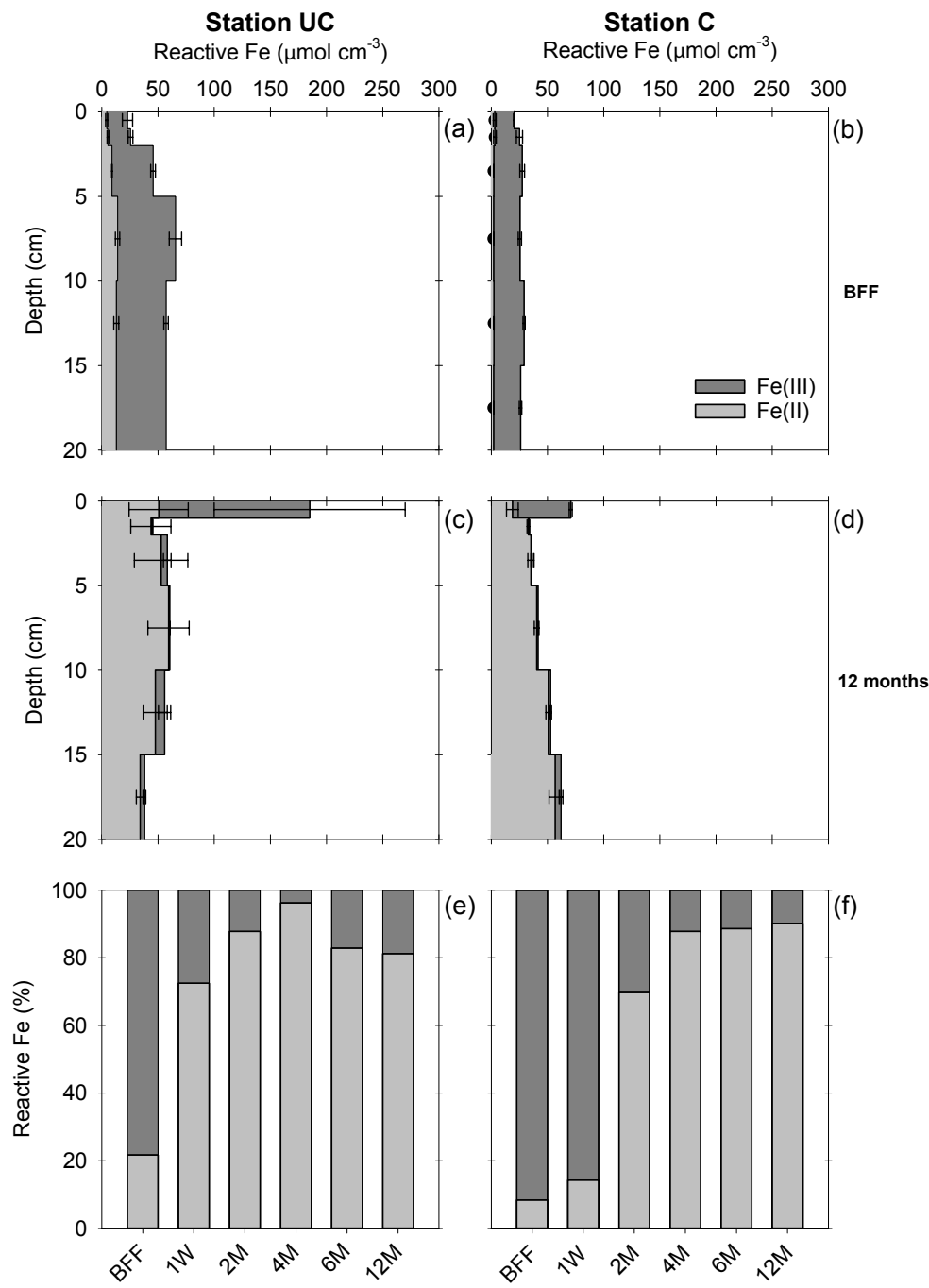

Figure 6. Upper panels (a, b) show concentration of reactive Fe(II) and Fe(III) in uncultivated (UC) and cultivated (C) soils before flooding (BFF) and 12 months after flooding. Lower panels (e, f) show the relative contributions of reactive Fe(II) and Fe(III) in the upper $20 \mathrm{~cm}$ at various times after flooding at 1 week (1W) and 2, 4, 6 and 12 months $(2 \mathrm{M}, 4 \mathrm{M}, 6 \mathrm{M}$ and 12M), respectively. Error bars indicate SEM $(n=3)$

ponentially with depth to zero at $15-20 \mathrm{~cm}$ depth. By months 2 and 4, SR occurred at all depths $\left(20-159 \mathrm{mmol} \mathrm{m}^{-2} \mathrm{~d}^{-1}\right)$. Afterwards SR decreased in the upper $15 \mathrm{~cm}$ while no SR was detected in the $15-20 \mathrm{~cm}$ depth interval.

Depth-integrated SR at station UC increased from 24 to $63 \mathrm{mmol} \mathrm{m}{ }^{-2} \mathrm{~d}^{-1}$ between week 1 and month 2, corresponding to 48 and $126 \mathrm{mmol} \mathrm{m}^{-2} \mathrm{~d}^{-1}$ carbon mineralization, respectively (Fig. 5). SR had decreased to $27.7 \mathrm{mmol} \mathrm{m}^{-2} \mathrm{~d}^{-1}$ after 12 months. SR increased during the first 4 months in $\mathrm{C}$ soil $\left(6-12 \mathrm{mmolm}^{-2} \mathrm{~d}^{-1}\right)$ and then decreased to $4 \mathrm{mmol} \mathrm{m}^{-2} \mathrm{~d}^{-1}$ after 12 months.

\subsection{Solid pools of $\mathrm{Fe}$ and $\mathrm{S}$}

Before flooding, $\mathrm{RFe}(\mathrm{II})$ in UC soil increased with depth from $4 \mu \mathrm{molcm} \mathrm{cm}^{-3}$ at $0-1 \mathrm{~cm}$ depth to $13 \mu \mathrm{mol} \mathrm{cm}{ }^{-3}$ at $15-$
$20 \mathrm{~cm}$ depth, while a corresponding increase in $\mathrm{RFe}$ (III) occurred from 19 to $44 \mu \mathrm{mol} \mathrm{cm}{ }^{-3}$ (Fig. 6). The RFe pools at station $\mathrm{C}$ were relatively constant with depth, on average 2.5 and $23 \mu \mathrm{mol} \mathrm{cm}{ }^{-3}$ for $\mathrm{RFe}(\mathrm{II})$ and $\mathrm{RFe}(\mathrm{III})$, respectively. Twelve months after flooding, RFe(II) in UC soil had increased to $34-59 \mu \mathrm{mol} \mathrm{cm}{ }^{-3}$, while $\mathrm{RFe}$ (III) had accumulated to $134.5 \pm 85 \mu \mathrm{mol} \mathrm{cm}{ }^{-3}$ in the top and decreased to an average of $4 \mu \mathrm{mol} \mathrm{cm}{ }^{-3}$ below. A similar trend was obtained in $\mathrm{C}$ soil with $\mathrm{RFe}(\mathrm{III})$ accumulating to $51.9 \pm 1.4 \mu \mathrm{mol} \mathrm{cm}^{-3}$ on the surface. In UC and $\mathrm{C}$ soil, total RFe initially consisted of 78 and $92 \% \mathrm{Fe}(\mathrm{III})$, respectively, while it was reduced to 19 and $10 \%$ by the end. Clearly, RFe(III) became reduced to $\mathrm{RFe}$ (II) during the experiment due to the anoxic conditions created by flooding. 

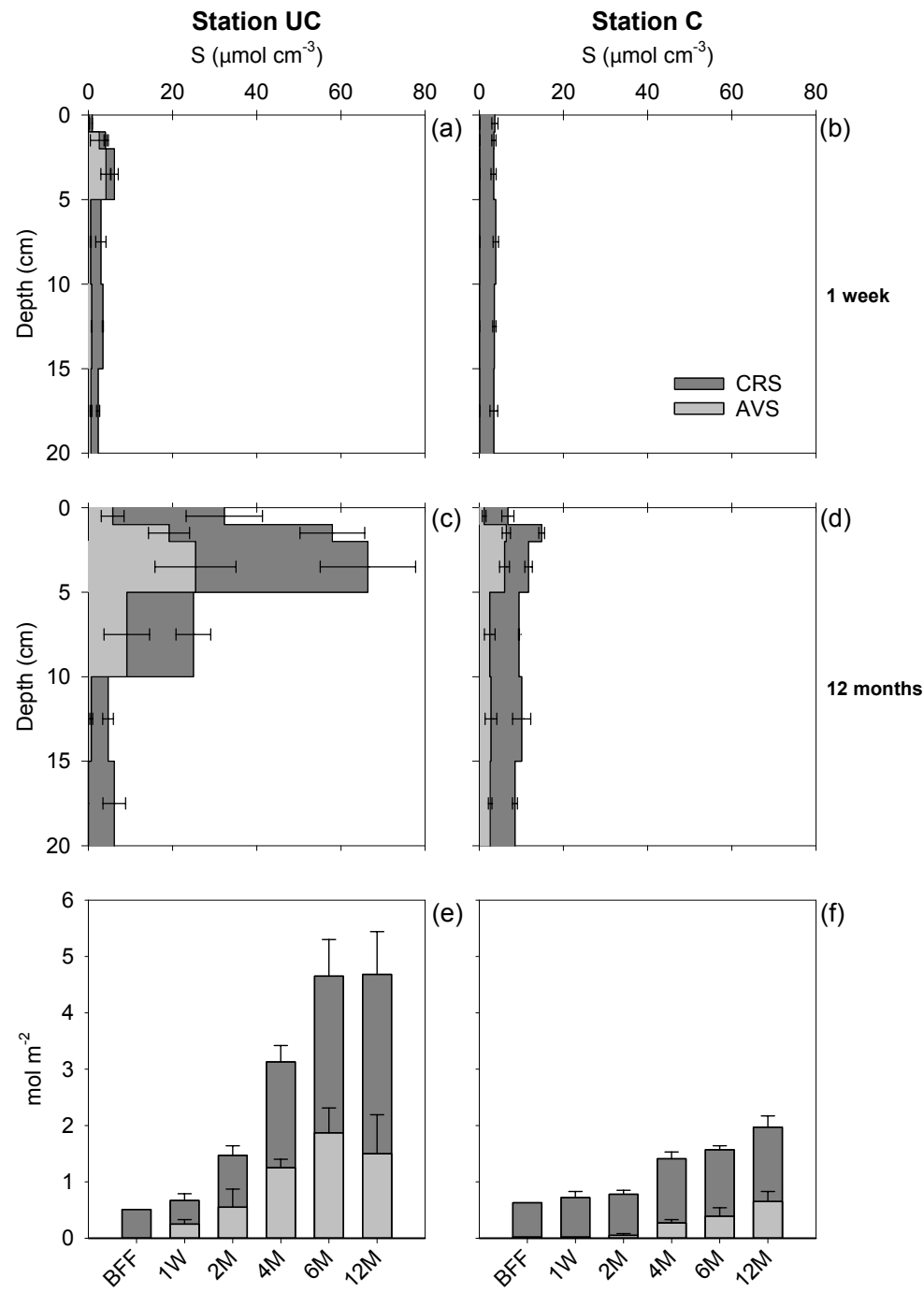

Figure 7. Upper panels (a, b) show concentration of chromium reducible sulfides (CRS) and acid volatile sulfides (AVS) in uncultivated (UC) and cultivated (C) soils before flooding (BFF) and 12 months after flooding. Lower panels (e, f) show the depth-integrated pools of AVS and $\mathrm{CRS}$ in the upper $20 \mathrm{~cm}$ at various times after flooding at 1 week (1W) and 2, 4, 6 and 12 months (2M, 4M, 6M and 12M), respectively. Error bars indicate $\operatorname{SEM}(n=3)$.

The RFe content was quite heterogeneous at the study sites and there were large variations between soil cores. Based on all the depth profiles obtained over the experiment, average total $\mathrm{Fe}$ content in UC and $\mathrm{C}$ soil was $19.3 \pm 2.8$ and $26.7 \pm$ $1.8 \mathrm{~mol} \mathrm{~m}^{-2}$, respectively.

Although the jar experiments suggested high SR in both soil types, dissolved sulfide $\left(\mathrm{TH}_{2} \mathrm{~S}\right)$ was never detected in the porewater. Instead, a large fraction of the sulfide produced during SR accumulated as AVS and CRS in both soil types (Fig. 7). One week after flooding, AVS and CRS in UC soil were low $\left(0.2-2.7 \mu \mathrm{mol} \mathrm{cm}{ }^{-3}\right)$, except at $2-5 \mathrm{~cm}$ depth, where AVS content was slightly elevated. Twelve months after flooding, AVS and CRS had increased to $25 \pm 10$ and $41 \pm 11 \mu \mathrm{mol} \mathrm{cm}{ }^{-3}$ at $2-5 \mathrm{~cm}$ depth, respectively, while no accumulation occurred below $10 \mathrm{~cm}$ depth.
A similar pattern was observed in $\mathrm{C}$ soil, in which AVS and CRS were initially constant with depth averaging 0.1 and $3.5 \mu \mathrm{mol} \mathrm{cm}{ }^{-3}$, respectively, and accumulated to $6.4 \pm 1$ and $8.4 \pm 0.7 \mu \mathrm{mol} \mathrm{cm} \mathrm{cm}^{-3}$ after 12 months of flooding, respectively. Over the whole experiment total sulfide accumulated as AVS and CRS gradually increased, from $0.5 \mathrm{~mol} \mathrm{~m}^{-2}$ before flooding to $4.7 \mathrm{~mol} \mathrm{~m}^{-2}$ after 12 months in UC soil, and from 0.63 to $2 \mathrm{~mol} \mathrm{~m}^{-2}$ in $\mathrm{C}$ soil.

\subsection{Budgets for SOC degradation}

Area-specific SOC pools were $710.9 \pm 54$ and $232.5 \pm$ $22 \mathrm{~mol} \mathrm{~m}^{-2}(n=18)$ in UC and C soil, respectively (Table 2). Total SOC degradation estimated as the sum of $\mathrm{TCO}_{2}$ and DOC effluxes, and porewater accumulation over the 1-year 
Table 2. Carbon budget table showing mean soil organic carbon $(\mathrm{SOC}) \pm \operatorname{SEP}(n=18)$ in uncultivated (UC) and cultivated (C) soil. Total time integrated efflux and accumulation of total carbon dioxide $\left(\mathrm{TCO}_{2}\right)$ and dissolved organic carbon (DOC) in porewater are also shown.

\begin{tabular}{lrr}
\hline Carbon budget $\left(\mathrm{mol} \mathrm{m}^{-2}\right)$ & Station UC & Station C \\
\hline Initial SOC pool & $710.9 \pm 54$ & $232.5 \pm 22$ \\
$\mathrm{TCO}_{2}$ efflux & 39.9 & 11.2 \\
$\mathrm{DOC}_{\text {efflux }}$ & 8.9 & 2.4 \\
$\mathrm{TCO}_{2}$ porewater accumulation & 0.1 & 0.8 \\
DOC porewater accumulation & 0.7 & 0.5 \\
\hline Total SOC degradation & 49.6 & 14.8 \\
\hline Percentage of SOC pool degraded & $7 \%$ & $6 \%$ \\
\hline
\end{tabular}

experiment was 49.6 and $14.8 \mathrm{~mol} \mathrm{~m}^{-2}$ at stations $\mathrm{UC}$ and C, respectively, corresponding to 7 and $6 \%$ of the SOC pools.

Total SOC mineralization to $\mathrm{TCO}_{2}$ was estimated as the sum of $\mathrm{TCO}_{2}$ efflux and porewater accumulation during the whole experiment (Table 3), which was 40.0 and $12.0 \mathrm{~mol} \mathrm{~m}^{-2}$ at stations $\mathrm{UC}$ and $\mathrm{C}$ respectively. The importance of anaerobic SOC degradation for total $\mathrm{TCO}_{2}$ mineralization could be calculated from jar experiments, and a total of 32.6 and $10.8 \mathrm{~mol} \mathrm{~m}^{-2} \mathrm{SOC}$ was converted to $\mathrm{TCO}_{2}$ anaerobically, corresponding to 82 and $90 \%$ of flux-based total $\mathrm{TCO}_{2}$ production at stations $\mathrm{UC}$ and $\mathrm{C}$, respectively. The SR measured in jar experiments corresponded to 25.3 and $4.3 \mathrm{~mol} \mathrm{~m}^{-2} \mathrm{CO}_{2}$ production at stations $\mathrm{UC}$ and $\mathrm{C}$ during the experiment. Thus 63 and $36 \%$ of the flux-based total $\mathrm{TCO}_{2}$ production was driven by SR in UC and C soil, respectively, starting at 30-40\% after 1 week and gradually increasing up to $100 \%$ by the end of the experiment. This means that the remaining 19 and $54 \%$ of the flux-based total $\mathrm{TCO}_{2}$ production was produced by other anaerobic processes than SR in $\mathrm{UC}$ and $\mathrm{C}$ soil, respectively (e.g. nitrate or Fe reduction).

\section{Discussion}

\subsection{Temporal trends in SOC degradation}

The UC and C soil had very different organic contents. UC soil had not been used for agriculture and organic matter consisting of dead and alive plant matter had accumulated in the topsoil (Table 1), while lower organic matter content was evident in $\mathrm{C}$ soil due to lower plant cover and regular mechanical soil reworking during agricultural cultivation (Benbi et al., 2015; Six et al., 1998). Consequently, the bulk SOC pool was three times higher in UC soil than in $\mathrm{C}$ soil. The source of soil organic matter at both stations was terrestrial and wetland plants, such as grasses, reed and herbs rich in cellulose and lignified tissues (Arndt et al., 2013; Sullivan, 1955). Such organic matter is refractory towards degradation in anaerobic marine sediments (Kristensen, 1990, 1994) compared to structurally simple phytoplankton, microphytobenthos and macroalgae, which are common organic carbon sources in coastal marine sediments (Dubois et al., 2012; Fry et al., 1977). It was therefore uncertain as to what extent the SOC at Gyldensteen Strand could serve as a substrate for developing microbial communities after the flooding with seawater. Nevertheless, we observed high heterotrophic activity (e.g. $\mathrm{O}_{2}$ uptake and $\mathrm{TCO}_{2}$ production) right after the flooding, indicating that at least part of the SOC in both soil types was readily available for microbial degradation.

Cleavage of particulate organic carbon to DOC by extracellular enzymes is the primary degradation step in waterlogged anoxic soils and sediments (Arnosti, 2011; Weiss et al., 1991). The produced DOC is thereafter converted into short chain fatty acids and acetate by microbially mediated fermentation and hydrolysis, which then are terminally oxidized to $\mathrm{CO}_{2}$, e.g. by SR (Canfield et al., 2005; Valdemarsen and Kristensen, 2010). DOC production can therefore generally be considered the rate-limiting step for organic carbon degradation. However, a small proportion of produced DOC is recalcitrant and may accumulate in soil porewater over time in an experimental set-up without advective porewater transport. In this experiment we observed high DOC concentrations in porewater and the highest DOC production in jar experiments as soon as 7 days after flooding with seawater (Figs. 3a, 5). Part of this DOC may have leached to the porewater, e.g. as a result of cell lysis due to flooding (Kalbitz et al., 2000), while the rest was produced by microbial degradation of particulate SOC (Kim and Singh, 2000). Microbial degradation of soil organic matter to DOC was initiated immediately after flooding irrespective of the shift to anoxic conditions. Differences in DOC production rates indicated that the availability of degradable SOC was clearly higher in UC soil compared to $\mathrm{C}$ soil following the overall difference in total SOC content. However, total DOC production ceased rapidly in both soil types and was close to zero after 1 year. Valdemarsen et al. (2014) similarly observed gradually decreasing DOC production over 2 years in eight different sediment types from Odense Fjord, indicating gradual depletion of degradable organic matter despite high sediment organic content and abundance of energetically favourable electron acceptors. It therefore appears that only a minor portion of SOC (6-7\%; Table 2) is available for microbial degradation under the present conditions (flooded with seawater and anoxic conditions). The low degradability of SOC after flooding probably reflects limitations of the anaerobic microbial communities on degradation of complex organic matter of terrestrial origin (Fors et al., 2008; Yucel et al., 2013).

Heterotrophic DOC oxidizing microbes were also active immediately after flooding as shown by initial $\mathrm{TCO}_{2}$ effluxes and high $\mathrm{TCO}_{2}$ production in the jar experiments 7 days after flooding (Figs. 2a, 5). Rapid microbial $\mathrm{CO}_{2}$ production has previously been observed in experiments with experimentally flooded soils (Chambers et al., 2011; Neubauer et 
Table 3. Budget table showing cumulated time-integrated total degradation to carbon dioxide $\left(\mathrm{TCO}_{2}\right)$ in flooded uncultivated (UC) and cultivated (C) soil, based on $\mathrm{TCO}_{2}$ fluxes and total anaerobic $\mathrm{TCO}_{2}$ production based on jar experiments. Estimated partitioning between aerobic respiration, sulfate reduction and other anaerobic respiration processes is also shown. Different times after flooding are indicated by $1 \mathrm{~W}$ (1 week) and 2M, 4M, 6M and 12M (2, 4, 6 and 12 months, respectively).

\begin{tabular}{|c|c|c|c|c|c|c|c|c|c|c|}
\hline & \multicolumn{5}{|c|}{ Station UC } & \multicolumn{5}{|c|}{ Station $\mathrm{C}$} \\
\hline & $1 \mathrm{~W}$ & $2 \mathrm{M}$ & $4 \mathrm{M}$ & $6 \mathrm{M}$ & $12 \mathrm{M}$ & $1 \mathrm{~W}$ & $2 \mathrm{M}$ & $4 \mathrm{M}$ & $6 \mathrm{M}$ & $12 \mathrm{M}$ \\
\hline Degradation to $\mathrm{TCO}_{2}\left(\mathrm{~mol} \mathrm{~m}^{-2}\right)$ & 2.07 & 10.4 & 18.8 & 27.4 & 40.0 & 0.5 & 2.7 & 5.0 & 6.6 & 12.0 \\
\hline Anaerobic degradation to $\mathrm{TCO}_{2}\left(\mathrm{~mol} \mathrm{~m}^{-2}\right)$ & 0.8 & 8.7 & 19.9 & 24.2 & 32.6 & 0.3 & 2.5 & 6.0 & 8.0 & 10.8 \\
\hline Aerobic respiration ( $\%$ of total) & 61 & 16 & 0 & 12 & 18 & 40 & 7 & 0 & 0 & 10 \\
\hline Sulfate reduction (\% of total) & 15 & 45 & 65 & 62 & 62 & 20 & 30 & 37 & 39 & 36 \\
\hline Other anaerobic respiration processes ( $\%$ of total) & 24 & 39 & 35 & 26 & 20 & 40 & 63 & 63 & 61 & 54 \\
\hline
\end{tabular}

al., 2013; Weston et al., 2011). In both soil types, $\mathrm{TCO}_{2}$ production in the surface soil increased over the first 2 months, peaked, and then decreased gradually towards the end. These temporal dynamics were out of phase with DOC availability, indicating that microbes oxidizing DOC to $\mathrm{CO}_{2}$ adapt slower to flooded conditions than fermenting and hydrolysing microbes. Similar cases of initial DOC production due to leaching and/or substrate hydrolysis outpacing fermentation and SR has been observed before (Arnosti et al., 1994), maybe due to lag response in the microbial community (Bruchert and Arnosti, 2003). Nevertheless, the majority ( $\sim 80 \%$; Table 2) of produced DOC over the whole experiment was oxidized completely to $\mathrm{TCO}_{2}$, while the rest effluxed to the overlying water $(\sim 19 \%)$ or accumulated in porewater $(\sim 1 \%)$.

\subsection{SOC degradation pathways}

$\mathrm{SO}_{4}^{2-}$ was an important electron acceptor in both soils and $\mathrm{SR}$ accounted for 63 and $36 \%$ of the total $\mathrm{TCO}_{2}$ production during the experiment in $\mathrm{UC}$ and $\mathrm{C}$ soil, respectively (Table 3). One week after flooding, active SR corresponding to $30-40 \%$ of anaerobic $\mathrm{TCO}_{2}$ production was detected in the jar experiment. The relative importance of SR increased gradually over the experiment and by the end accounted for up to $100 \%$ of the anaerobic $\mathrm{TCO}_{2}$ production in both soil types. This is in accordance with Weston et al. (2006), who measured SR in freshwater marsh soil exposed to saltwater in anoxic flow through reactors, and found that the relative importance of SR for total $\mathrm{TCO}_{2}$ production increased from $18 \%$ initially to $>95 \%$ after 4 weeks. The delay in SR probably reflects a lag phase for the community of $\mathrm{SO}_{4}^{2-}$ reducing microbes to respond to elevated $\mathrm{SO}_{4}^{2-}$ levels. The delay in SR could also reflect initial competition with other $\mathrm{TCO}_{2}$ producing pathways (e.g. $\mathrm{NO}_{3}^{-}$and $\mathrm{Fe}$ reduction) in the time right after flooding when $\mathrm{NO}_{3}^{-}$and oxidized $\mathrm{Fe}$ might have been abundant. However, as the soil became reduced due to increased SOC degradation activity and limited $\mathrm{O}_{2}$ supply, electron acceptors other than $\mathrm{SO}_{4}^{2-}$ were rapidly depleted and SR became the dominant respiration pathway.
By combining results from flux and jar experiments, it was possible to confine the relative importance of different microbial respiration pathways in flooded soils. The difference between $\mathrm{TCO}_{2}$ effluxes (aerobic and anaerobic processes) and $\mathrm{TCO}_{2}$ production in jar experiments (anaerobic processes) suggested that aerobic respiration only played a minor role in the flooded soils (18 and $10 \%$ in UC and C soil, respectively). On the other hand, SR was quantitatively a very important pathway, constituting 63 and $36 \%$ of total C-mineralization to $\mathrm{TCO}_{2}$ in $\mathrm{UC}$ and $\mathrm{C}$ soil, respectively. Hence 19 (UC) to $54 \%$ (C) of $\mathrm{TCO}_{2}$ production occurred by respiration processes that are not directly accounted for. Weston et al. (2006) found that Fe reduction was responsible for about $60 \%$ of $\mathrm{CO}_{2}$ production in the first 4 days after saltwater intrusion in coastal soils. When considering the high initial concentrations and the rapid decrease in soil RFe(III) in our experiment (Fig. 6), respiratory Fe-reduction was probably an important respiration process initially. However, based on this experiment it was not possible to distinguish between biological and chemical Fe-reduction.

\subsection{Fate of SOC}

In this study we observed that only $6-7 \%$ of the total SOC pools in coastal soils were degraded by microbial processes in the first year after flooding with seawater. The low final SOC degradation rates, and especially the very low final DOC production in both soil types, suggest that the majority of SOC present in soils at the time of flooding will be permanently buried due to the limited ability of anaerobic microbial communities to degrade complex organic matter of terrestrial origin (Burdige, 2007; Canfield, 1994; Hedges and Keil, 1995). For comparison Neubauer et al. (2013) similarly found long-term reduction of degradation rates and lability of SOC pools in a tidal freshwater marsh experiencing saltwater intrusion, which also supports preservation of SOC. Hence flooding of coastal soils due to sea-level rise or intentional flooding by managed realignment may lead to significant C-preservation. At Gyldensteen Strand SOC burial will be in the order of $48 \pm 6 \times 10^{3} \mathrm{~kg} \mathrm{SOC} \mathrm{ha}^{-1}$ (average $\pm \mathrm{SEM}$, 
$n=30$ ) when considering a detailed investigation of the soil characteristics down to $20 \mathrm{~cm}$ depth (T. Valdemarsen, unpublished results). However, this C-preservation does not constitute a permanent $\mathrm{C}$-sink as it only relates to the SOC buried in the soils at the time of flooding.

\subsection{Efficient Fe-driven sulfide buffering in flooded soils}

Accumulation of free $\mathrm{H}_{2} \mathrm{~S}$ is often seen in metabolically active organic enriched marine sediments, where it has toxic effects on benthic fauna (Hargrave et al., 2008; Valdemarsen et al., 2010). It was therefore a concern whether free $\mathrm{H}_{2} \mathrm{~S}$ would accumulate in the soils from Gyldensteen after flooding, since this could hamper the succession of benthic fauna as well as overall ecological developments. However, despite the extremely high initial SR rates in the flooded soils, comparable to SR measured beneath fish farms (Bannister et al., 2014; Holmer et al., 2003), no accumulation of free $\mathrm{H}_{2} \mathrm{~S}$ occurred in any of the soil types. Dent (1986), Portnoy and Giblin (1997), and Weston et al. (2011) observed a similar lack of $\mathrm{H}_{2} \mathrm{~S}$ accumulation in soils introduced to saltwater, suggesting that newly flooded soils have a high capacity to buffer $\mathrm{H}_{2} \mathrm{~S}$. Budget considerations suggest that most of the produced $\mathrm{H}_{2} \mathrm{~S}$ was immediately re-oxidized, e.g. with $\mathrm{O}_{2}$ in the surface soils, while a significant proportion (37 and $93 \%$ in $\mathrm{UC}$ and $\mathrm{C}$ soil, respectively) precipitated as different $\mathrm{Fe}-\mathrm{S}$ compounds, for instance $\mathrm{FeS}$ and $\mathrm{Fe}_{3} \mathrm{~S}_{4}$ in $\mathrm{AVS}$ and $\mathrm{FeS}_{2}$ and $\mathrm{S}^{0}$ in CRS (Reddy and DeLaune, 2008; Rickard and Morse, 2005; Valdemarsen et al., 2010). The depth profiles of solid $\mathrm{Fe}$ and $\mathrm{S}$ showed that sulfide precipitation occurred at the same depths at which active SR was measured, i.e. in the upper $10 \mathrm{~cm}$ in UC soil and down to $20 \mathrm{~cm}$ depth in $\mathrm{C}$ soil. The decreasing microbial activity and increasing Fe(II) over time will create a long-term sulfide buffering capacity in the soil (Schoepfer et al., 2014).

\section{Conclusions}

In this study a rapid stimulation of heterotrophic microbial degradation of SOC was observed in two different soils (uncultivated or cultivated) following flooding with seawater. Degradation rates peaked in the first 2 months after flooding, and thereafter gradually declined to low levels after 1 year. Microbial SR was rapidly established in both soil types and was the dominating respiration pathway. Nevertheless, despite extremely high SR rates, $\mathrm{H}_{2} \mathrm{~S}$ did not accumulate in the soils as it was re-oxidized with $\mathrm{O}_{2}$ at the soil-water interface or precipitated with Fe to form AVS and CRS. All three hypotheses stated initially were confirmed. Total SOC degradation activity in the tested soils clearly did depend on SOC content (hypothesis 1) and was 3-fold higher in organic rich uncultivated soil compared to the organic poor cultivated soil. However, only a small proportion of SOC (6-7\%) was degraded in the first year after flooding, and when consid- ering the low final SOC degradation rates, it appears that a large proportion of SOC is non-degradable under anoxic marine conditions and will essentially be preserved after flooding (hypothesis 2). Hence this study suggests that in soils flooded with seawater the majority of SOC will be permanently preserved.

Data availability. Values from Figs. 2 to 7 can be downloaded at https://doi.org/10.1594/PANGAEA.880926.

Competing interests. The authors declare that they have no conflict of interest.

Acknowledgements. We thank technician Birthe Christiansen for help with chemical analyses. Further we thank Erik Kristensen and Marianne Holmer for valuable discussions and for initiating research at Gyldensteen Strand. This work was supported by a grant from the Danish National Research Foundation (grant number: DNRF53) and the Aage V. Jensen Nature Foundation.

Edited by: Caroline P. Slomp

Reviewed by: Edouard Metzger and two anonymous referees.

\section{References}

Ardon, M., Morse, J. L., Colman, B. P., and Bernhardt, E. S.: Drought-induced saltwater incursion leads to increased wetland nitrogen export, Glob. Change Biol., 19, 2976-2985, 2013.

Ardon, M., Helton, A. M., and Bernhardt, E. S.: Drought and saltwater incursion synergistically reduce dissolved organic carbon export from coastal freshwater wetlands, Biogeochemistry, 127, 411-426, 2016.

Arndt, S., Jorgensen, B. B., LaRowe, D. E., Middelburg, J. J., Pancost, R. D., and Regnier, P.: Quantifying the degradation of organic matter in marine sediments: A review and synthesis, EarthSci. Rev., 123, 53-86, 2013.

Arnosti, C.: Microbial extracellular enzymes and the marine carbon cycle, Annual Review of Marine Science, 3, 401-425, 2011.

Arnosti, C., Repeta, D. J., and Blough, N. V.: Rapid bacterial degradation of polysaccharides in anoxic marine systems, Geochim. Cosmochim. Ac., 58, 2639-2652, 1994.

Bannister, R. J., Valdemarsen, T., Hansen, P. K., Holmer, M., and Ervik, A.: Changes in benthic sediment conditions under an Atlantic salmon farm at a deep, well-flushed coastal site, Aquacult. Environ. Interact., 5, 29-47, 2014.

Benbi, D. K., Brar, K., Toor, A. S., and Singh, P.: Total and labile pools of soil organic carbon in cultivated and undisturbed soils in northern India, Geoderma, 237, 149-158, 2015.

Boer, W., Folman, L. B., Summerbell, R. C., and Boddy, L.: Living in a fungal world: impact of fungi on soil bacterial niche development, FEMS Microbiol. Rev., 29, 795-811, 2005.

Bruchert, V. and Arnosti, C.: Anaerobic carbon transformation: experimental studies with flow-through cells, Mar. Chem., 80, 171183, 2003. 
Burdige, D. J.: Preservation of organic matter in marine sediments: controls, mechanisms, and an imbalance in sediment organic carbon budgets?, Chem. Rev., 107, 467-485, 2007.

Canfield, D. E.: Factors influencing organic carbon preservation in marine sediments, Chem Geol, 114, 315-329, 1994.

Canfield, D. E., Kristensen, E., and Thamdrup, B.: Aquatic geomicrobiology, Adv. Mar. Biol., 48, 1-599, 2005.

Chambers, L. G., Reddy, K. R., and Osborne, T. Z.: Short-Term Response of Carbon Cycling to Salinity Pulses in a Freshwater Wetland, Soil Sci. Soc. Am. J., 75, 2000-2007, 2011.

Chambers, L. G., Osborne, T. Z., and Reddy, K. R.: Effect of salinity-altering pulsing events on soil organic carbon loss along an intertidal wetland gradient: a laboratory experiment, Biogeochemistry, 115, 363-383, 2013.

Church, J. A., Clark, P. U., Cazenave, A., Gregory, J. M., Jevrejeva, S., Levermann, A., Merrifield, M. A., Milne, G. A., Nerem, R. S., Nunn, P. D., Payne, A. J., Pfeffer, W. T., Stammer, D., and Unnikrishnan, A. S.: Sea Level Change, in: Climate Change: The Physical Science Basis. Contribution of Working Group I to the Fifth Assessment Report of the Intergovernmental Panel on Climate Change, edited by: Stocker, T. F., Qin, D., Plattner, G.-K., Tignor, M., Allen, S. K., Boschung, J., Nauels, A., Xia, Y., Bex, V., and Midgle, P. M., Cambridge University Press, Cambridge, United Kingdom and New York, NY, USA, 2013.

Cline, J. D.: Spectrophotometric Determination of Hydrogen Sulfide in Natural Waters, Limnol. Oceanogr., 14, 454-458, 1969.

Cooper, N. J.: The use of 'managed retreat' in coastal engineering, P. I. Civil Eng., 156, 101-110, 2003.

Dent, D.: Acid sulphate soils: a baseline for research and development, International Institute for Land Reclamation and Improvement, Netherlands, 1986.

Dubois, S., Savoye, N., Gremare, A., Plus, M., Charlier, K., Beltoise, A., and Blanchet, H.: Origin and composition of sediment organic matter in a coastal semi-enclosed ecosystem: An elemental and isotopic study at the ecosystem space scale, J. Marine Syst., 94, 64-73, 2012.

Dziejowski, J. E., Rimmer, A., and Steenhuis, T. S.: Preferential movement of oxygen in soils?, Soil Sci. Soc. Am. J., 61, 16071610, 1997.

FitzGerald, D. M., Fenster, M. S., Argow, B. A., and Buynevich, I. V.: Coastal impacts due to sea-level rise, Annu. Rev. Earth Pl. Sc., 36, 601-647, 2008.

Fors, Y., Nilsson, T., Risberg, E. D., Sandström, M., and Torssander, P.: Sulfur accumulation in pinewood (Pinus sylvestris) induced by bacteria in a simulated seabed environment: Implications for marine archaeological wood and fossil fuels, Int. Biodeter. Biodegr., 62, 336-347, 2008.

Fossing, H. and Jørgensen, B.: Measurement of Bacterial Sulfate Reduction in Sediments: Evaluation of a Single-Step Chromium Reduction Method, Biogeochemistry, 8, 205-222, 1998.

Franzluebbers, A. J.: Soil organic carbon in managed pastures of the southeastern United States of America, in: Grassland carbon sequestration: management, policy and economics, edited by: Abberton, M., Conant, R., and Batello, C., Integrated Crop Management, Rome, 2010.

French, J. R.: Hydrodynamic modelling of estuarine flood defence realignment as an adaptive management response to sea-level rise, J. Coastal Res., 24, 1-12, 2008.
Fry, B., Scalan, R. A., and Parker, P. L.: Stable carbon isotope evidence for two sources of organic matter in coastal sediments: seagrasses and plankton, Geochim. Cosmochim. Ac., 41, 18751877, 1977.

Gedan, K. B., Kirwan, M. L., Wolanski, E., Barbier, E. B., and Silliman, B. R.: Tiohe present and future role of coastal wetland vegetation in protecting shorelines: answering recent challenges to the paradigm, Climatic Change, 106, 7-29, 2011.

Glud, R. N.: Oxygen dynamics of marine sediments, Mar. Biol. Res., 4, 243-289, 2008.

Hall, P. O. J. and Aller, R. C.: Rapid, Small-Volume, Flow Injection Analysis for $\Sigma \mathrm{CO}_{2}$ and $\mathrm{NH}_{4}^{+}$in Marine and Freshwaters, Limnol. Oceanogr., 37, 1113-1119, 1992.

Hargrave, B. T., Holmer, M., and Newcombe, C. P.: Towards a classification of organic enrichment in marine sediments based on biogeochemical indicators, Mar. Pollut. Bull., 56, 810-824, 2008.

Hedges, J. I. and Keil, R. G.: Sedimentary organic matter preservation: an assessment and speculative synthesis, Mar. Chem., 49, 81-115, 1995.

Hedin, R. S.: The Use of Measured and Calculated Acidity Values to Improve the Quality of Mine Drainage Datasets, Mine Water and the Environment, 25, 146-152, 2006.

Herbert, E. R., Boon, P., Burgin, A. J., Neubauer, S. C., Franklin, R. B., Ardón, M., Hopfensperger, K. N., Lamers, L. P. M., and Gell, P.: A global perspective on wetland salinization: ecological consequences of a growing threat to freshwater wetlands, Ecosphere, 6, 206, https://doi.org/10.1890/ES14-00534.1, 2015.

Holmer, M., Duarte, C. M., Heilskov, A., Olesen, B., and Terrados, $\mathrm{J}$.: Biogeochemical conditions in sediments enriched by organic matter from net-pen fish farms in the Bolinao area, Philippines, Mar. Pollut. Bull., 46, 1470-1479, 2003.

Jørgensen, B. B.: Bacteria and Marine Biogeochemistry, in: Marine Geochemistry, edited by: Schulz, H. D. and Zabel, M., Springer, Berlin Heidelberg New York, 2006.

Kalbitz, K., Solinger, S., Park, J. H., Michalzik, B., and Matzner, E.: Controls on the dynamics of dissolved organic matter in soils: A review, Soil Sci., 165, 277-304, 2000.

Kim, Y. S. and Singh, A. P.: Micromorphological characteristics of wood biodegradation in wet environments: A review, IAWA J., 21, 135-155, 2000.

Kristensen, E.: Characterization of Biogenic Organic Matter by Stepwise Thermogravimetry (STG), Biogeochemistry, 9, 135159, 1990.

Kristensen, E.: Decomposition of Macroalgae, Vascular Plants and Sediment Detritus in Seawater: Use of Stepwise Thermogravimetry, Biogeochemistry, 26, 1-24, 1994.

Kristensen, E. and Andersen, F. O.: Determination of organic carbon in marine sediments: a comparison of two $\mathrm{CHN}$-analyzer methods, Journal of Experimental Marine Biology and Ecology, 109, 15-23, 1987.

Kristensen, E. and Hansen, K.: Decay of plant detritus in organicpoor marine sediment: Production rates and stoichiometry of dissolved C and N compounds, J. Mar. Res., 53, 675-702, 1995.

Kristensen, E. and Holmer, M.: Decomposition of plant materials in marine sediment exposed to different electron acceptors $\left(\mathrm{O}_{2}\right.$ $\mathrm{NO}_{3}^{-}$, and $\mathrm{SO}_{4}^{2-}$ ), with emphasis on substrate origin, degradation kinetics, and the role of bioturbation, Geochim. Cosmochim. Ac., 65, 419-433, 2001. 
Lovley, D. R. and Phillips, E. J.: Rapid assay for microbially reducible ferric iron in aquatic sediments, Appl. Environ. Microb., 53, 1536-1540, 1987.

MacDonald, J. D., Costello, L. R., and Berger, T.: An evaluation of soil aeration status around healthy and declining oaks in an urban environment in California, Journal of Aboriculture, 19, 209-219, 1993.

Moses, C. O., Nordstrom, D. K., Herman, J. S., and Mills, A. L.: Aqueous Pyrite Oxidation by Dissolved-Oxygen and by Ferric Iron, Geochim. Cosmochim. Ac., 51, 1561-1571, 1987.

Neira, J., Ortiz, M., Morales, L., and Acevedo, E.: Oxygen diffusion in soils: Understanding the factors and processes needed for modeling, Chil. J. Agr. Res., 75, 35-44, 2015.

Neubauer, S. C., Franklin, R. B., and Berrier, D. J.: Saltwater intrusion into tidal freshwater marshes alters the biogeochemical processing of organic carbon, Biogeosciences, 10, 8171-8183, https://doi.org/10.5194/bg-10-8171-2013, 2013.

Pethick, J.: Estuarine and tidal wetland restoration in the United Kingdom: Policy versus practice, Restor. Ecol., 10, 431-437, 2002

Portnoy, J. W.: Salt Marsh Diking and Restoration: Biogeochemical Implications of Altered Wetland Hydrology, Environ. Manage., 24, 111-120, 1999.

Portnoy, J. W. and Giblin, A. E.: Biogeochemical effects of seawater restoration to diked salt marshes, Ecol. Appl., 7, 1054-1063, 1997.

Quintana, C. O., Kristensen, E., and Valdemarsen, T.: Impact of the invasive polychaete Marenzelleria viridis on the biogeochemistry of sandy marine sediments, Biogeochemistry, 115, 95-109, 2013.

Reddy, K. R. and DeLaune, R. D.: Biogeochemistry of Wetlands: Science and Applications, CRC Press, Boca Raton, 2008.

Rickard, D. and Morse, J. W.: Acid volatile sulfide (AVS), Mar. Chem., 97, 141-197, 2005.

Roman, C. T. and Burdick, D. M.: Tidal Marsh Restoration: A Synthesis of Science and Management, Island Press, Washington, DC, 2012.

Schmidt, M. W. I., Torn, M. S., Abiven, S., Dittmar, T., Guggenberger, G., Janssens, I. A., Kleber, M., Kogel-Knabner, I., Lehmann, J., Manning, D. A. C., Nannipieri, P., Rasse, D. P., Weiner, S., and Trumbore, S. E.: Persistence of soil organic matter as an ecosystem property, Nature, 478, 49-56, 2011.

Schoepfer, V. A., Bernhardt, E. S., and Burgin, A. J.: Iron clad wetlands: Soil iron-sulfur buffering determines coastal wetland response to salt water incursion, J. Geophys. Res.-Biogeo., 119, 2209-2219, 2014.

Six, J., Elliott, E. T., Paustian, K., and Doran, J. W.: Aggregation and soil organic matter accumulation in cultivated and native grassland soils, Soil Sci. Soc. Am. J., 62, 1367-1377, 1998.
Sjøgaard, K., Treusch, A., and Valdemarsen, T.: Carbon degradation rates, sulfate reduction rates and iron composition in soils flooded with seawater at Gyldensteen Strand, Denmark, PANGAEA, https://doi.org/10.1594/PANGAEA.880926, 2017.

Stenak, M.: Inddæmningerne på Nordfyn, in: De inddæmmede landskaber - en historisk geografi, Landbohistorisk Selskab, Sønderborg, 2005.

Stookey, L. L.: Ferrozine - A New Spectrophotometric Reagent for Iron, Anal. Chem., 42, 779-781, 1970.

Sullivan, J. T.: Cellulose and Lignin in Forage Grasses and Their Digestion Coefficients, J. Anim. Sci., 14, 710-717, 1955.

Sutton-Grier, A. E., Keller, J. K., Koch, R., Gilmour, C., and Megonigal, J. P.: Electron donors and acceptors influence anaerobic soil organic matter mineralization in tidal marshes, Soil Biol. Biochem., 43, 1576-1583, 2011.

Valdemarsen, T. and Kristensen, E.: Degradation of dissolved organic monomers and short-chain fatty acids in sandy marine sediment by fermentation and sulfate reduction, Geochim. Cosmochim. Ac., 74, 1593-1605, 2010.

Valdemarsen, T., Kristensen, E., and Holmer, M.: Sulfur, carbon, and nitrogen cycling in faunated marine sediments impacted by repeated organic enrichment, Mar. Ecol.-Prog. Ser., 400, 37-53, 2010.

Valdemarsen, T., Quintana, C. O., Kristensen, E., and Flindt, M. R.: Recovery of organic-enriched sediments through microbial degradation: implications for eutrophic estuaries, Mar. Ecol.Prog. Ser., 503, 41-58, 2014.

Weiss, M. S., Abele, U., Weckesser, J., Welte, W., Schiltz, E., and Schulz, G. E.: Molecular architecture and electrostatic properties of a bacterial porin, Science, 254, 1627-1630, 1991.

Weston, N. B., Dixon, R. E., and Joye, S. B.: Ramifications of increased salinity in tidal freshwater sediments: Geochemistry and microbial pathways of organic matter mineralization, J. Geophys. Res., 111, G01009, https://doi.org/10.1029/2005JG000071, 2006.

Weston, N. B., Vile, M. A., Neubauer, S. C., and Velinsky, D. J.: Accelerated microbial organic matter mineralization following saltwater intrusion into tidal freshwater marsh soils, Biogeochemistry, 102, 135-151, 2011.

Wolters, M., Garbutt, A., and Bakker, J. P.: Salt-marsh restoration: evaluating the success of de-embankments in north-west Europe, Biol. Conserv., 123, 249-268, 2005.

Yucel, M., Galand, P. E., Fagervold, S. K., Contreira-Pereira, L., and Le Bris, N.: Sulfide production and consumption in degrading wood in the marine environment, Chemosphere, 90, 403-409, 2013. 